\title{
HUBUNGAN ANTARA MINAT MENJADI GURU DENGAN PRESTASI BELAJAR MAHASISWA
}

\section{Zakiyatul Lutfiyah $^{1}$, Sugeng Utaya ${ }^{2}$, Singgih Susilo $^{3}$}

Email: zakiyatul08@gmail.com, sugeng.utaya.fis@um.ac.id, singgih.susilo.fis@um.ac.id

\begin{abstract}
Abstrak: Prestasi belajar merupakan hasil akhir usaha belajar. Prestasi belajar bisa diukur melalui simbol angka. Pada tingkat perguruan tinggi, prestasi belajar bisa dilihat berdasarkan indeks prestasi kumulatif (IPK). IPK dengan kategori pujian menjadi tujuan semua mahasiswa. Prestasi belajar sangat mempengaruhi hasil lulusan sarjana yang berkualitas. Hal itu termasuk dalam fungsi prestasi belajar, maka diperlukan pengetahuan untuk mengetahui faktor apa saja yang memberikan sumbangan terbesar. Minat menjadi guru merupakan faktor instrinsik yang penting dalam prestasi belajar mahasiswa pendidikan geografi Universitas Negeri Malang. Penelitian ini bertujuan untuk mengetahui hubungan minat menjadi guru dengan prestasi belajar mahasiswa. Rancangan penelitian kuantitatif menggunakan eksplanatory. Hasil analisis menggunakan uji korelasional menunjukkan nilai signifikansi sebesar 0,000 . Jadi nilai signifikansi 0,000 $<0,05$, maka H0 ditolak. Hasil analisis korelasional diketahui bahwa 0,465 yang berarti ada hubungan minat menjadi guru dengan prestasi belajar.
\end{abstract}

Kata Kunci: minat menjadi guru dan prestasi belajar

\begin{abstract}
The learning achievement is the end result of learning effort. The learning achievement can be measured through number symbols. At the college level, academic achievement can be seen based on grade point average (GPA). CPI by category compliments the goal of all students. The learning achievement greatly affect the outcome of qualified graduates. It was included in the function of learning achievement, the necessary knowledge to determine what factors contributed most. Interest in becoming a teacher is an intrinsic factors that are important in the achievement of students of geography education, State University of Malang. This study aims to determine the relationship of interest to be a teacher with students' achievement. Quantitative research design using explanatory. Results of analysis using correlation test showed a significance value of 0,000 . So the significance value $0,000<0,05$, then $\mathrm{H}_{0}$ is rejected. The results of correlation analysis known that 0,465 meaning there is interest in becoming teachers with academic achievement.
\end{abstract}

Keywords: interest in becoming a teacher and learning achievement

\section{PENDAHULUAN}

Situasi dikatakan belajar jika seseorang menerima, mendapat, dan menyerap suatu informasi baru yang dapat merubah dirinya. Perubahan yang terjadi bisa terlihat dari tingkah laku dan pola pikir yang menjadi lebih baik. Suatu perubahan yang

\footnotetext{
${ }^{1}$ Mahasiswa Pascasarjana UM

${ }^{2}$ Dosen Jurusan Geografi FIS UM

${ }^{3}$ Dosen Jurusan Geografi FIS UM
} 
terjadi akibat belajar dikontrol oleh hasil yang didapat. Menurut Skinner (dalam Pravesti, 2014) menyatakan bahwa tindakan pebelajar (behavior or response) yang dimaksudkan adalah siswa lebih dikontrol oleh konsekuensi yang menyertai tingkah laku tersebut daripada peristiwa yang mendahului. Hasil belajar yang didapat ini berupa nilai tugas dan ujian.

Jika hasil belajar mahasiswa dirasakan baik, maka dia akan mempertahankan bahkan meningkatkan cara atau pola belajar yang telah dilakukan. Sehingga konsekuensi dari nilai tersebut adalah dilakukannya pola belajar yang berulangulang. Sebaliknya jika hasil belajarnya kurang baik, maka siswa akan mencari cara dengan mengubah pola belajar. Hal tersebut dinamakan belajar, dimana siswa akan mengalami perubahan tingkah laku dan pola pikir.

Perubahan tingkah laku dari hasil belajar dapat dilihat pada akhir evaluasi yang disebut dengan prestasi belajar. Prestasi belajar menurut Winkel (2005) merupakan bukti keberhasilan yang telah dicapai oleh seseorang. Jadi prestasi belajar merupakan hasil akhir yang dicapai oleh siswa setelah melakukan usaha belajar.

Tinggi rendahnya prestasi belajar dapat dipengaruhi oleh berbabagai faktor. Sesuai dengan pendapat Slameto (1995) prestasi belajar dipengaruhi oleh faktor intrinsik dan ekstrinsik. Faktor intrinsik muncul dari dalam diri sendiri, meliputi: fisik dan psikologis. Faktor fisik berhubungan dengan kondisi fisik umum seperti penglihatan dan pendengaran. Faktor psikologis menyangkut faktor-faktor non fisik, seperti: minat, motivasi, bakat, kebiasaan belajar, sikap dan kesehatan men- tal. Faktor ekstrinsik berasal dari luar diri seseorang yang meliputi: fisik dan sosial. Faktor fisik menyangkut kondisi lingkungan tempat belajar, sarana dan perlengkapan belajar, materi pelajaran. Faktor sosial menyangkut dukungan sosial dan hubungan budaya.

Dari beberapa hal yang mempengaruhi prestasi belajar, faktor intrinsik menjadi yang terpenting dalam pencapaian keberhasilan. Hal ini sesuai pendapat Sitohang (2009) menyatakan bahwa sumber terkaya untuk bahan belajar berasal dari dalam diri sendiri. Berdasarkan pendapat tersebut, dapat dikatakan bahwa faktor internal perlu diperhatikan dalam pencapaian prestasi belajar.

Prestasi belajar dapat diukur melalui simbol angka atau huruf. Pada tingkat perguruan tinggi, prestasi belajar dapat dilihat berdasarkan indeks prestasi kumulatif (IPK). Menurut Ni'mah (2014) prestasi belajar dilihat dari IPK mahasiswa dari semester satu sampai akhir semester.

Motivasi merupakan faktor instrinsik yang penting dalam peningkatan prestasi belajar. Menurut Suryabrata (2002) motivasi adalah keadaan yang terdapat dalam diri seseorang yang mendorongnya untuk melakukan aktivitas tertentu guna pencapaian suatu tujuan. Timbulnya motivasi yang dimiliki oleh seseorang dikarenakan adanya kebutuhan dalam dirinya. Kebutuhan dalam motivasi dapat dibagi atas lima tingkatan. McClelland David (dalam Djaali, 2011) mengemukakan bahwa diantara kebutuhan hidup manusia terdapat tiga macam kebutuhan, yaitu berprestasi, berafiliasi, dan memperoleh makanan. Motivasi berprestasi lebih menyukai suatu tantangan dan memiliki tujuan pencapain. Motivasi yang sangat berhu- 
bungan terhadap prestasi belajar, yakni motivasi berprestasi.

Motivasi berprestasi merupakan dorongan seseorang untuk mencapai tingkatan tertinggi dalam meraih tujuan berdasarkan standar tertentu. McClelland dalam The Encyclopedia Dictionary of Psychology yang disusun oleh Hare dan Lamb (dalam Djaali, 2011) mengungkapkan bahwa motivasi berprestasi berhubungan dengan pencapaian beberapa standar kepandaian atau standar keahlian. Motivasi dapat dibedakan menjadi dua, yakni intrinsik dan ektrinsik. Motivasi berprestasi termasuk dalam intrinsik yang berhubungan dalam prestasi belajar siswa. Jika motivasi untuk berprestasi tinggi maka prestasi belajar ikut tinggi.

\section{METODE}

Rancangan penelitian kuantitatif menggunakan cross sectional. Ditinjau dari hubungan antar variabel, penelitian ini dirancang sebagai penelitian korelasional. Tujuannya untuk mengetahui hubungan minat menjadi guru dengan prestasi belajar. Variabel bebas dalam penelitian ini adalah minat menjadi guru, sedangkan prestasi belajar sebagai variabel terikat.

Penelitian ini menggunakan angket untuk mengukur minat menjadi guru. Adapun populasi dalam penelitian ini adalah seluruh mahasiswa Program Studi Pendidikan Geografi angkatan 2012 Universitas Negeri Malang yang berjumlah 175 mahasiswa. Sampel dalam penelitian ini ditentukan dengan teknik random sampling dan diperoleh 64 mahasiswa.

Instrumen penelitian menggunakan angket yang diadopsi dari study interest questionnaire (SHI) yang dikembangkan oleh Schiefele, dkk (1993) dan instrumen penelitian Setiaji (2013). Penggunaan study interest questionnaire (SHI) yang telah menjadi standar dalam pengukuran minat belajar, perlu dikombinasikan dengan instrumen penelitian Setiaji (2013).

Kombinasi tersebut menyesuaikan penelitian ini yakni minat menjadi guru. Penelitian Setiaji (2013) digunakan untuk pelengkap dari angket SHI agar sesuai dengan variabel dalam penelitian minat menjadi guru. Hal lainnya dikarenakan dalam pengukuran minat menjadi guru, bukan hanya dari faktor minat belajar geografi saja melainkan juga minat dalam keprofesian guru. Keunggulan dari instrumen Setiaji (2013) adalah telah dilakukannya uji validitas dan reliabilitas.

Angket yang digunakan telah dilakukan uji reliabilitas. Dari uji tersebut diketahui bahwa angket SHI telah reliabel dengan koefisien 0,86 (Schiefele, 1988) dan 0,84 (Muller, 2004). Sementara reliabel dengan koefisien 0,87 dari instrumen penelitian Setiaji (2013). Study interest questionnaire (SHI) yang dikombinasi dengan angket Setiaji (2013) menjadi 23 item yang mencakup tiga indikator. Ketiga indikator tersebut berupa perasaan, penilaian, orientasi instrinsik.

Analisis yang digunakan adalah uji korelasional menggunakan bantuan SPSS 16.00 for windows. Jika hasil signifikan hitung $>\alpha(0,05)$ maka $\mathrm{H}_{0}$ ditolak, yang berarti bahwa terdapat hubungan yang signifikan antara minat menjadi guru dengan prestasi belajar mahasiswa pendidikan geografi angkatan 2012 Universitas Negeri Malang. 
HASIL

Data minat menjadi guru yang diperoleh dari angket dapat dilihat pada tabel 1 berikut ini.

Tabel 1. Deskripsi Minat Menjadi Guru

\begin{tabular}{lllll}
\hline \begin{tabular}{l} 
Minat $\begin{array}{l}\text { Menjadi } \\
\text { Guru }\end{array}$ \\
\cline { 2 - 5 }
\end{tabular} & Min. & Max. & Mean & $\begin{array}{l}\text { Standar } \\
\text { Deviasi }\end{array}$ \\
\hline
\end{tabular}

Persentase minat menjadi guru dapat dilihat pada diagram 1 berikut ini.

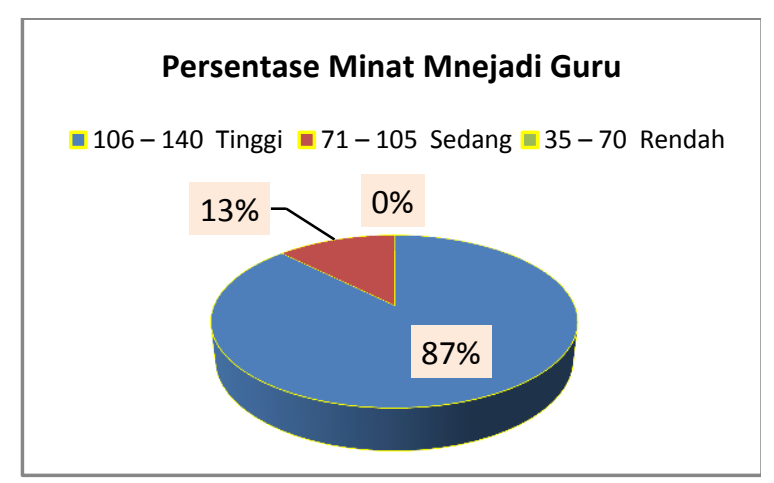

Diagram 1. Persentase minat menjadi guru

Data prestasi belajar dapat dilihat dari hasil berikut ini.

Tabel 2. Deskripsi Pretasi Belajar

\begin{tabular}{lcccc}
\hline $\begin{array}{l}\text { Prestasi } \\
\text { Belajar }\end{array}$ & Mean & Min & Max & $\begin{array}{c}\text { Standar } \\
\text { Devisasi }\end{array}$ \\
\cline { 2 - 5 } & 3,31 & 2,51 & 3,59 & 0,20 \\
\hline
\end{tabular}

Persentase IPK dapat dilihat pada diagram 2 berikut ini.

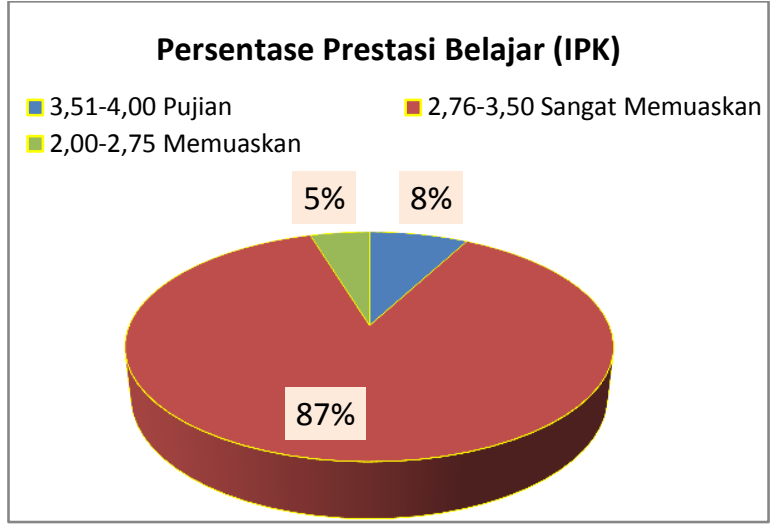

Diagram 2. Persentase IPK

\section{Uji Hipotesis}

Hasil uji korelasi minat menjadi guru dengan prestasi belajar dapat dilihat pada tabel 3 berikut ini.

Tabel 3. Hasil Uji Korelasi

\begin{tabular}{lll|l}
\hline & & IPK & $\begin{array}{l}\text { Minat Menjadi } \\
\text { Guru }\end{array}$ \\
Pearson Correlation & IPK & 1.000 & .465 \\
& Minat & .465 & 1.000 \\
Sig. (1-tailed) & IPK &. & .000 \\
& Minat & .000 &. \\
\hline & IPK & 64 & 64 \\
\hline & Minat & 64 & 64 \\
\hline
\end{tabular}

Berdasarkan uji korelasi dapat diketahui hasil signifikansi minat menjadi guru sebesar 0,000. Jadi hasil sig. $>\alpha$ $(0,05)$, maka $\mathrm{H}_{0}$ ditolak yang signifikan antara minat menjadi guru dengan prestasi belajar mahasiswa pendidikan geografi angkatan 2012 Universitas Negeri Malang. Dilihat dari hasil person correlation sebesar 0,465 yang artinya ada hubungan minat menjadi guru dengan prestasi belajar. Jadi dapat disimpulkan terdapat hubungan yang signifikan minat menjadi guru dengan prestasi belajar.

\section{PEMBAHASAN}


84

Zakiyatul Lutfiyah, Sugeng Utaya, Singgih Susilo. Hubungan Antara Minat Menjadi Guru Dengan Prestasi Belajar Mahasiswa

\section{Hubungan Minat Menjadi Guru terhadap Prestasi Belajar}

Minat menjadi guru mahasiswa pendidikan geografi angkatan 2012 tergolong tinggi. Minat menjadi guru yang tinggi dapat membuat mahasiswa meraih prestasi belajar yang tinggi. Prestasi belajar dapat dilihat berdasarkan indeks prestasi kumulatif (IPK) yang telah ditempuh lebih dari enam semester oleh mahasiswa pendidikan geografi angkatan 2012 Universitas Negeri Malang.

Prestasi belajar yang dilihat dari IPK terbagi menjadi tiga kategori, yaitu: memuaskan $(2,00-2,75)$, sangat memuaskan (2,76-3,50), dengan pujian (3,514,00). Mahasiswa pendidikan geografi angkatan 2012 memperoleh IPK yang beragam dari memuaskan hingga pujian. Mahasiswa dengan IPK memuaskan memiliki minat menjadi guru yang sedang. Mahasiswa dengan IPK sangat memuaskan memiliki minat menjadi guru sedang hingga tinggi. Mahasiswa dengan IPK pujian memiliki minat menjadi guru sedang dan tinggi.

Hasil analisis deskriptif diketahui bahwa terdapat hubungan yang signifikan minat menjadi guru terhadap prestasi belajar. Selain dari analisis deskriptif, hubungan minat menjadi guru terhadap prestasi belajar dapat dilihat dari uji korelatif untuk mengetahui sumbangannya. Sumbangan minat menjadi guru terhadap prestasi belajar sebesar 41,5\%. Sumbangan ini lebih besar dari variabel motivasi berprestasi dan kebiasaan belajar. Jadi dapat dikatakan minat menjadi guru berpengaruh terhadap prestasi belajar. Hal ini sejalan dengan pendapat Heinze (dalam Adnyana, 2013) menyatakan bahwa minat adalah ...long-term and independent of present situations, that individuals, who achieve the highest level of internalization regarding the adoption of values and objectives related to a learning topic consistently and permanently into their value and belief system.

Maksud kalimat di atas adalah minat bertahan dalam jangka waktu yang lama dan bebas dari situasi saat ini. Seseorang yang memiliki minat yang tinggi cenderung untuk mengintegrasikan tujuan yang berkaitan dengan topik belajar secara konsisten dan secara permanen menjadi sebuah nilai dan sistem. Minat menjadi guru mahasiswa pendidikan geografi Universitas Negeri Malang tergolong sedang dan tinggi. Tinggi sedangnya minat menjadi guru yang berhubungan terhadap prestasi belajar dapat dipengaruhi oleh banyak faktor. Menurut Hurlock (2010:144) faktor yang mempengaruhi minat seseorang terhadap suatu profesi antara lain sikap orang tua, prestise pekerjaan, kekaguman pada seseorang, kemampuan, kesesuaian seks (gender), otonomi dalam bekerja, stereotip budaya dan pengalaman pribadi.

Berdasarkan hasil penelitian tidak sedikit mahasiswa yang berminat pada profesi guru bahkan tidak sedikit dari mereka yang hendak melanjutkan studi keguruannya. Siswa yang memiliki minat tinggi dia akan lebih cenderung memilih untuk melanjutkan pendidikan ke perguruan tinggi agar dapat mencapai cita-cita yang diingikannya (Rokhimah, 2015). Ketertarikan mahasiswa pendidikan geografi terhadap minat menjadi guru juga tidak lepas dari faktor luar diri sendiri, yakni keluarga. 
Keluarga memiliki peranan penting dalam mempengaruhi minat anak. Seorang anak bisa memiliki minat menjadi guru bila memiliki orang tua, kerabat, saudara, atau orang terdekat lainnya yang berprofesi guru. Kecenderungan hal tersebut dalam satu keluarga yang berprofesi guru akan menurun. Hal ini tidak lepas dari sikap orang tua yang mendidik anaknya menjadi seorang yang kelak dapat menjadi kebanggaan dalam keluarga. Sikap orang tua berprofesi guru yang perhatian dapat membentuk minat anak menjadi guru dan mampu mempengaruhi prestasi belajar.

Faktor prestise pekerjaan guru adalah suatu anggapan yang tertanam dalam diri maupun dari luar mengenai profesi guru. Jika mahasiswa yang memiliki anggapan yang baik terhadap profesi guru, maka dengan mudah mereka menerima hal tersebut. Profesi guru yang dianggap baik karena mampu berbagi ilmu atau menyalurkannya dan menjadi panutan di masyarakat, akan mampu menimbulkan keinginan menjadi guru. Keinginan menjadi guru yang kuat akan mampu membuat mahasiswa pendidikan geografi meraih prestasi belajar yang baik. Tidak sedikit pula mahasiswa yang memberikan tanggapan sangat sesuai dan sesuai untuk pernyataan mengenai prestise profesi guru.

Kekaguman mahasiswa terhadap profesi guru memberikan hubungan besar-kecilnya minat terhadap prestasi belajar. Beberapa mahasiswa pendidikan geografi yang menjadi responden memberi jawaban bahwa mereka tertarik terhadap profesi guru dikarenakan kagum terhadap pengajar baik guru/dosen. Kekaguman yang dimiliki mahasiswa tersebut dapat memicu keinginan untuk menjadi guru yang dikaguminya. Dengan mengikuti perkuliahan jurusan kependidikan geografi, mahasiswa yang memiliki kekaguman terhadap pengajar mampu meraih prestasi yang baik.

Kemampuan yang dimiliki mahasiswa merupakan bagian dari beberapa pernyataan yang ada di lembar instrumen. Kemampuan termasuk dalam pengukuran diri mahasiswa apakah sesuai menjadi guru. Banyak mahasiswa pendidikan geografi yang menjawab sesuai dan tidak sesuai untuk pernyataan mengenai kemampuan diri. Ketidakpercayaan diri mahasiswa terhadap kemampuannya sendiri dapat mengecilkan minat menjadi guru. Hal inilah yang membuat kategori sedang minat menjadi guru yang berhubungan terhadap prestasi belajar. Ketidakpercayaan kemampuan akan membuat mahasiswa rendah diri, sehingga mereka tidak dapat mengeluarkan seluruh kemampuannya.

Mahasiswa Pendidikan Geografi angkatan 2012 Universitas Negeri Malang telah menempuh lebih dari enam semester dan telah menyelesaikan praktik perkuliahan lapangan (PPL). Pengalaman PPL yang langsung mengajar di sekolah menengah atas (SMA) yang telah mereka tempuh. Pengalaman pribadi yang berharga tersebut menjadi salah satu pemicu minat menjadi guru dan semangat untuk meraih prestasi belajar. Hal ini sejalan dengan Ni'mah (2014) minat profesi guru dapat dilihat dari beberapa indikator salah satunya, yakni kemauan.

Hasil penelitian minat menjadi guru terhadap prestasi belajar didukung oleh penelitian sebelumnya. Ada beberapa penelitian sebelumnya, yakni Meter 
(1999), Sukasni (2012), Saputra (2013), Setiaji (2013), Ni'mah (2014), dan Astarini (2015). Penelitian Meter (1999) berjudul "Hubungan Antara Kemampuan Akademik, Motivasi Kerja, dan Minat Menjadi Guru Dengan Profesionalisme Guru Pada Sekolah Dasar di Kecamatan Kubutambahan Kabupaten Buleleng". Hasil penelitian yang didapat menyatakan bahwa terdapat hubungan minat profesi guru, Locus of Control Internal, peran guru pamong dan prestasi belajar terhadap kesiapan mahasiswa menjadi guru pada jurusan pendidikan ekonomi baik secara simultan maupun parsial.

Penelitian sebelumnya dilakukan oleh Sukasni (2012) dengan judul "Hubungan Antara Motivasi Belajar dan Prestasi Belajar dengan Minat Menjadi Guru Mahasiswa PTM JPTK FKIP UNS Surakarta Tahun Akademik 2011/2012". Adapun hasil penelitian dari Sukasni (2012) adalah 1) Ada hubungan yang signifikan antara motivasi belajar dengan minat menjadi guru mahasiswa Program Studi Pendidikan Teknik Mesin JPTK FKIP UNS Surakarta Tahun Akademik 2011/2012. (2) Ada hubungan yang signifikan antara prestasi belajar dengan minat menjadi guru mahasiswa Program Studi Pendidikan Teknik Mesin JPTK FKIP UNS Surakarta Tahun Akademik 2011/2012. (3) Ada hubungan yang signifikan secara bersama-sama antara motivasi belajar dan prestasi belajar dengan minat menjadi guru mahasiswa Program Studi Pendidikan Teknik Mesin JPTK FKIP UNS Surakarta Tahun Akademik 2011/2012.

Penelitian minat menjadi guru oleh Saputra (2013) menyatakan bahwa ada hubungan antara minat menjadi guru dengan kesiapan menjadi guru pendidikan jasmani pada mahasiswa PJKR angkatan 2009 FIK-UNY. Penelitian Setiaji (2013) berjudul "Pengaruh Motivasi Karir Mengajar, Career Self Efficacy dan Status Ekonomi yang Dimediasi Minat Menjadi Guru terhadap Prestasi Akademik Mahasiswa Pendidikan Ekonomi Universitas Negeri Semarang". Hasil dari penelitian Setiaji (2013) adalah 1) minat menjadi guru berpengaruh positif dan sig. terhadap prestasi akademik, 2) motivasi karir mengajar berpengaruh positif dan sig. terhadap prestasi akademik melalui minat menjadi guru, 3) Career Self Efficacy berpengaruh positif dan sig terhadap prestasi akademik melalui minat menjadi guru, dan 4) status ekonomi berpengaruh positif dan sig. terhadap prestasi akademik melalui minat menjadi guru.

Penelitian terdahulu dari Ni'mah (2014) berjudul "Pengaruh Minat Profesi Guru, Locus of Control Internal, Peran Guru Pamong Dan Prestasi Belajar Terhadap Kesiapan Mahasiswa Menjadi Guru Pada Jurusan Pendidikan Ekonomi Fakultas Ekonomi Universitas Negeri Semarang". Adapun hasil dari penelitian tersebut adalah terdapat pengaruh minat profesi guru, Locus of Control Internal, peran guru pamong dan prestasi belajar terhadap kesiapan mahasiswa menjadi guru pada jurusan pendidikan ekonomi baik secara simultan maupun parsial.

Penelitian berjudul "Pengaruh Self Efficacy, Prestise Profesi Guru dan Status Sosial Ekonomi Orang Tua terhadap Minat Menjadi Guru. Akuntansi Pada Mahasiswa Pendidikan Akuntansi 2011 FE UNNES" oleh Astarini (2015). Hasil penelitian yang didapat menyatakan bahwa secara simultan self efficacy, prestise 
profesi guru dan status sosial ekonomi orang tua terhadap minat menjadi guru akuntansi sebesar $49,9 \%$. Sisanya $50,1 \%$ dipengaruhi oleh faktor lain yang tidak diungkap dalam penelitian tersebut. Secara parsial besarnya pengaruh pengaruh self efficacy terhadap minat mahasiswa menjadi guru akuntansi sebesar $43,29 \%$, pengaruh prestise profesi terhadap minat menjadi guru akuntansi sebesar 9,42\%, dan pengaruh status sosial ekonomi orang tua terhadap minat mahasiswa menjadi guru akuntansi 5,90\%.

\section{KESIMPULAN}

\section{Kesimpulan}

Berdasarkan hasil dan pembahasan yang telah dijabarkan, maka kesimpulan yang dapat diberikan adalah terdapat hubungan yang signifikan minat menjadi guru dengan prestasi belajar. Hal ini dapat dibuktikan melalui hasil sig. dan person corellation uji korelasi. Hasil sig. minat menjadi guru $0,000<0,05$, maka $\mathrm{H}_{0}$ ditolak, berarti ada hubungan signifikan minat menjadi guru dengan prestasi belajar. Person Corellation uji korelasi sebesar 0,465 maka terdapat hubungan korelasi yang cukup antara minat menjadi guru dengan pretasi belajar.

\section{SARAN}

Adapun saran yang dapat diberikan, yakni: 1) bagi dosen, dosen dapat meningkatkan minat menjadi guru dengan memberikan contoh yang baik kepada mahasiswanya. 2) Bagi penelitian selanjutnya, dapat mengkombinasikan faktor lain untuk mengetahui hubungannya dengan prestasi belajar.

\section{DAFTAR RUJUKAN}

Adnyana, I Gusti Made. 2013. Penggunaan EFI SCANNER sebagai media Pembelajaran untuk meningkatkan minat, motivasi, dan prestasi belajar siswa. Jurnal Pendidikan Vokasi, Vol.3, No.2, Juni 2013. (online). (http://journal.uny.ac.id/index.php/ jpv/article/view/1601) diakses 27 Juli 2015.

Astarini, Ita. 2015. Pengaruh Self Efficacy, Prestise Profesi Guru dan Status Sosial Ekonomi Orang Tua terhadap Minat Menjadi guru Akuntansi pada Mahasiswa Pendidikan Akuntansi 2011 FE UNNES. Economic Education Analysis Journal, EEAJ 4(2) (2015). (online). (http://lib.unnes.ac.id/21063 /1/7101411042-s.pdf) diakses pada 25 November 2015.

Djaali. 2011. Psikologi pendidikan. Jakarta: Bumi Aksara.

Hurlock, Elizabeth. 2010. Perkembangan Anak Jilid 2. Jakarta: Penerbit Erlangga.

Sitohang, Sonang. 2009. Penyuluhan serta Peranannya terhadap Industri Mikro dan Kecil di Indonesia. Jurnal Akutansi, Manajemen Bisnis dan Sektor Publik (JAMBS) issn 1829-9857, (online), (http://jurnal.stiesia.ac.id/article/do wnload_selection_article) diakses tanggal 30 April 2016.

Meter, I Gede. 1999. Hubungan Antara Kemampuan Akademik, Motivasi Kerja, Dan Minat Menjadi Guru Dengan Profesionalisme Guru Pada Sekolah Dasar Di Kecamatan Kubutambahan Kabupaten Buleleng. Tesis tidak diterbitkan. Malang: Pascasarjana.

Müller, R.H. dan C.M. Keck. (2004). Challenges and Solutions for The Delivery of Biotech Drugs - A Review of Drug Nanocrystal Technol- 
Zakiyatul Lutfiyah, Sugeng Utaya, Singgih Susilo. Hubungan Antara Minat Menjadi Guru Dengan Prestasi Belajar Mahasiswa

ogy and Lipid Nanoparticles. J. Biotech. 113: 151-170.

Ni'mah, Fahmi Ulin. 2014. Hubungan Minat Profesi Guru, Locus Of Control Internal, Peran Guru Pamong Dan Prestasi Belajar Terhadap Kesiapan Mahasiswa Menjadi Guru Pada Jurusan Pendidikan Ekonomi Fakultas Ekonomi Universitas Negeri Semarang. Economic Education Analysis Journal 3 (2) (2014) ISSN 2252-6544, (online), (http://journal.unnes.ac.id/ sju/index.php/eeaj/search/results) diakses 28 Juli 2015.

Pravesti, Cindy A. 2014. Model Prestasi Belajar Siswa (Hubungan Sebab Akibat Faktor Minat, Motivasi, dan Kebiasaan Belajar terhadap Prestasi Belajar). Tesis tidak diterbitkan. Malang: Pascasarjana.

Rokhimah, Siti. 2015. Pengaruh Dukungan Sosial dan Efikasi Diri Terhadap Minat Melanjutkan Pendidikan Ke Perguruan Tinggi Pada Siswa SMA Negeri 1 Tenggarong Seberang. eJournal Psikologi, 2015, 3 (1):382-39. (online), (http:// Psikologi.fisipunmul.ac.id/ejournal) diakses 17 Maret 2015.

Saputra, Muhammad G. 2013. Hubungan Antara Minat Menjadi Guru Dengan Kesiapan Menjadi Guru Pendidikan Jasmani Pada Mahasiswa PJKR Angkatan 2009 FIKUNY. Jurnal Pendidikan Jasmani Kesehatan dan Rekreasi, Vol. 2, No. 4, April 2013. (online). (journal. Student.uny.ac.id) diakses tanggal $14 \quad$ November 2015.Slameto. 1995. Belajar dan Faktor-Faktor yang Mempengaruhi. Jakarta: PT Rineka Cipta.

Schiefele, Ulrich. 1991. Interet, learning, and motivation. Journal Educational Psychologist, 26 (1991) 3 \&
4, S. 299-32. (online). (http://www.unco.edu/cebs/psychol ogy/kevinpugh/motivation_project/ resources/schiefele91.pdf) diakses 29 Februari 2016.

Setiaji, Khasan. 2013. Pengaruh Motivasi Karir Mengajar, Career Self Efficacy dan Status Sosial Ekonomi yang Dimediasi Minat Menjadi Guru Terhadap Prestasi Akademik Mahasiswa Pendidikan Ekonomi Universitas Negeri Semarang. Tesis tidak diterbitkan. Malang: Pascasarjana UM.

Slameto. 1995. Belajar dan FaktorFaktor yang Mempengaruhi. Jakarta: PT Rineka Cipta.

Sukasni, Ninik Sri. Hubungan Antara Motivasi Belajar dan Prestasi Belajar Dengan Minat Menjadi Guru Mahasiswa PTM JPTK FKIP UNS Surakarta Tahun Akademik 2011/2012. Jurnal Pendidikan. (online).

(https://core.ac.uk/download/files/4 78/12346070.pdf) diakses 01 September 2015.

Suryabrata, Sumadi. 2002. Psikologi Pendidikan. Jakarta: PT Raja Grafindo Perrsada.

Winkel, W. S. 2005. Psikologi Pengajaran. Yogyakarta: Media Abadi. 